Jurnal Indonesia Sosial Teknologi: p-ISSN: 2723 - 6609

e-ISSN : 2745-5254

Vol. 2, No. 11 November 2021

\title{
PENGELOLAAN SUMBER DAYA AIR BERDASARKAN PERSPEKTIF HUKUM INDONESIA
}

\section{Kartika Chandra Kirana.}

Jurusan Ilmu Hukum Universitas Tarumanegara Jakarta

Email: chankikartika@gmail.com

\begin{abstract}
Abstrak
Dalam konteks ekonomi, keadilan harus ditegakkan bagi pengguna air. Hal ini dapat diterjemahkan menjadi setiap orang berhak untuk mengembangkan sumber daya air. Jika sumber daya air berada di wilayah tersebut, maka yang berhak menggunakan dan mengelola sumber daya air tersebut adalah masyarakat setempat, pemerintah daerah, dan pengusaha di wilayah tersebut. Oleh karena itu, masyarakat berhak mengambil air untuk kebutuhannya sendiri, pemerintah daerah berhak memperoleh hasil dari pengelolaan sumber daya air, dan pengusaha berhak mengelola sumber daya air sebagai pengusaha. Dalam hal ini selalu berkaitan dengan masalah keadilan. Pasal 2 UU Sumber Daya Air menekankan prinsip keadilan bagi setiap pengguna air di negara kita, yang mengatur bahwa salah satu prinsip pengelolaan sumber daya air adalah prinsip keadilan. Keadilan yang dimaksud dalam undang-undang berarti bahwa pengelolaan sumber daya air dilakukan atas dasar kesetaraan di semua lapisan sosial masyarakat. Untuk memastikan bahwa semua warga negara memainkan peran dan memiliki kesempatan yang sama untuk mencapai hasil yang sebenarnya. Di era otonomi daerah, pengaturan dan pengelolaan sumber daya alam, khususnya sumber daya air, hal ini dianggap semakin rumit, jika tidak dipahami secara utuh atau menyeluruh dapat menimbulkan konflik antar daerah otonom. Secara ekonomi, tanpa kerjasama dan interaksi dengan daerah lain, tidak ada daerah yang bisa mandiri. Keterkaitan ekonomi dan ekologi antar wilayah menunjukkan adanya perbedaan karakteristik dan potensi sumberdaya yang dimiliki oleh masing-masing wilayah.
\end{abstract}

Kata kunci: adil; air; pengelolaan.

\section{Abstract}

In the economic context, justice must be served for water users. This can be translated into everyone has the right to develop water resources. If the water resources are located in the area, then those who have the right to use and manage the water resources are the local community, local government, and businessmen in the area. Therefore, the community has the right to take water for their own needs, the local government has the right to get results from the management of water resources, and entrepreneurs have the right to manage water resources as entrepreneurs. In this case it is always related to the issue of justice. Article 2 of the Water Resources Law emphasizes the principle of justice for every water user in our country, which stipulates that one of the principles of water resource management is 
the principle of justice. The justice referred to in the law means that the management of water resources is carried out on an equal basis in all social strata of society.to ensure that all citizens play a role and have equal opportunities to achieve actual results. In the era of regional autonomy, the regulation and management of natural resources, especially water resources, is considered to be increasingly complicated, if not understood in its entirety or comprehensively it can lead to conflicts between autonomous regions. Economically, without cooperation and interaction with other regions, no region can be independent. Economic and ecological linkages between regions show that there are differences in the characteristics and potential of resources owned by each region

Keywords: fair; water; management.

\section{Pendahuluan}

Air merupakan anugerah dari Tuhan Yang Maha Esa, dan memberikan manfaat bagi seluruh rakyat Indonesia untuk mencapai kemakmuran di segala bidang. Di Indonesia, para founding fathers sangat menyadari pentingnya sumber daya air (Silalahi, 2008). Hal ini termasuk dalam Pasal 33 (3) Undang-Undang Dasar Negara Republik Indonesia Tahun 1945 (UUD NRI 1945), yang menyatakan bahwa "bumi dan air dan kekayaan alam yang terkandung di dalamnya dikuasai oleh negara dan dipergunakan untuk sebesar-besarnya kemakmuran rakyat". orang orang."

Selain sebagai kebutuhan dasar manusia, air juga merupakan barang publik yang tidak dimiliki oleh siapa pun, tetapi dikelola secara kolektif dalam bentuk milik bersama secara global, Penggunaan air meliputi kegiatan pertanian, industri, rumah tangga, rekreasi dan lingkungan (Tesha, 2019). Jelas, semua orang membutuhkan air bersih.

Pasokan air bersih menurun dari tahun ke tahun, tetapi air adalah sumber daya yang dapat diperbarui (Jocom, Kameo, Utami, \& Kristijanto, 2016). Di beberapa belahan dunia, kebutuhan akan air bersih semakin meningkat seiring dengan permintaan akan air yang melebihi persediaan dan populasi dunia yang terus bertambah. Paradigma tradisional ini bersebrangan dengan paradigma pengelolaan air modern dimana didasarkan kepada nilai ekonomi yang melekat pada air.Paradigma pengelolaan air modern ini didasarkan kepada asumsi sumber daya air yang terbatas dan langka serta kebutuhan untuk menginvestasikan atau menyediakan air bersih sebagai realisasi dari hak setiap warga negara ( Sudarwanto, 2015).

Air bukanlah benda yang tidak terbatas. Jika satu orang menggunakan semua air, tidak ada air yang tersisa untuk orang lain. Karena air adalah bagian yang sangat penting dalam kehidupan, maka sangatlah penting bagi Negara untuk mengelola sumber daya air (Barthes, 2012). Hak atas air diberikan oleh undang-undang. Pentingnya UU SDA dalam perlindungan HAM. Karena hukum adalah panglima yang menjunjung tinggi hak-hak dasar. Indonesia adalah negara hukum, yaitu UU No. 11 tentang Pengairan tahun 1974. Undang-undang ini mencakup sumber air baik di darat maupun di bawah air (Pasal 1 Ayat (3) Undang-Undang Nomor 11 Tahun 1974, 1974). 
Tujuan penelitian ini adlah Menjelaskan bagaimana pengelolaan sumber daya air yang baik dan benar dan, Menjelaskan penegakan hukum bagi pelanggaran Izin pemanfaatan sumber daya air.

\section{Metode Penelitian}

Penelitian atau yang disebut research dalam bahasa Inggris adalah pekerjaan mencari, dalam arti khusus berarti menemukan pengetahuan yang tepat untuk menjawab dan/atau memecahkan masalah yang dihadapi manusia dalam kehidupan. Atau kembangkan dan uji kebenaran/pengetahuan, atau dapatkan jawaban atas pertanyaan". Metode penelitian adalah sebagai berikut:

1. Pendekatan Penelitian ini menggunakan pendekatan yuridis empiris, yaitu pendekatan dari sudut pandang ketentuan hukum / perundang-undangan yang berlaku dan dipadukan bersama data primer yang diperoleh dari lapangan tentang pengaturan sumber daya air

2. Objek Penelitian dalam kajian hukum ini ialah mengenai Sumber Daya Air

3. Subyek Penelitian Bupati Kabupaten Lampung Barat, Kepala Dinas dan Direktur PDAM.

4. Sumber Data didalam penelitian ini terdiri dari :

a. Data primer: data yang diperoleh peneliti langsung dari subyek penelitian.

b. Data sekunder : Data diperoleh peneliti melalui membaca literatur yang relevan dengan penelitian ini dan melalui studi literatur dan dokumenter.

5. Teknik Pengumpulan Data

a. Data primer yang dilakukan dengan wawancara. Kemudian wawancara ini dilakukan dengan cara interview dengan subyek hukum/responden yang sebelumnya telah ditentukan.

b. Data sekunder dilakukan dengan mengkaji dan menelusuri putusan Mahkamah Konstitusi Nomor 85/PUU-XI/2013 dan Peraturan perundangundangan yang relevan, mencari, menemukan dan mengkaji berbagai dokumen dan literatur lain yang lebih relevan.

6. Pengolahan data adalah kegiatan membaca dan mengorganisasikan data penelitian dengan cara yang dapat ditafsirkan. Karena sifat kualitatif dari data dalam penelitian ini, pengolahan data melibatkan persiapan, pengkodean, dan penyajian naratif. Pengeditan adalah peninjauan data Anda sehingga Anda dapat melakukan pembukuan dalam situasi yang sebenarnya. Editing dilakukan dengan mengoreksi data yang salah dan menambahkan data yang hilang. Coding adalah proses mengubah suatu unit informasi menjadi kode atau simbol. Setelah semua data terkumpul, hasilnya akan ditampilkan dalam format deskriptif. Analisis data kualitatif adalah analisis data deskriptif, metode penelitian di mana pernyataan lisan atau tertulis responden dan perilaku aktual juga diselidiki dan diselidiki secara keseluruhan. 


\section{Hasil dan Pembahasan \\ Pengertian Sumber Daya Air}

Air memegang peranan yang sangat penting dalam kehidupan manusia, tanpa air yang cukup selama lebih dari seminggu, manusia tidak akan dapat bertahan hidup (Soraya, 2014). Selain untuk bertahan hidup sesuai dengan sentralitasnya, air juga berperan penting dalam menunjang keberhasilan sektor pertanian. Peran hukum sebagai sarana untuk mengembangkan dan melaksanakan keadilan/ketertiban sosial. Peranan hukum didalam pembangunan sumber daya air harus sangat mampu menjamin suatu perubahan yang tertib dan tentunya teratur sesuai dengan arah yang telah ditentukan.tentu saja akan mengarah pada yang terbaik. Sumber daya air yang tersedia memiliki potensi. Hal-hal seperti irigasi dan infrastruktur, tetapi tidak termasuk produksi ternak.

Air adalah sebuah potensi yang sangat luar biasa bagi manusia dan yang paling utama dalam kehidupan karena memiliki kegunaan yang meliputi penggunaan di bidang pertanian, Industri, rumah tangga, rekreasi, dan aktivitas lingkungan (Suntari, 2017). Kedudukan air dalam kehidupan Berbangsa dan Bernegara. Air juga merupakan hak umum, air merupakan sumber daya alam yang esensial bagi kehidupan manusia, dan air merupakan unsur yang penting dalam sistem pengelolaan lingkungan. Air merupakan salah satu kebutuhan pokok umat manusia, baik untuk memenuhi kebutuhan hidup, maupun sebagai suatu komunitas tertentu, sebagai penghormatan terhadap leluhur dan kepercayaan (Maridi, 2015). Air adalah ciptaan Tuhan yang maha esa, sehingga hak atas air bukan hanya milik manusia, tetapi juga untuk seluruh kehidupan di dunia, baik itu hewan, tumbuhan, maupun manusia itu sendiri. semua makhluk hidup milik Tuhan memiliki kebutuhan dasar: air dan udara. Untuk mendukung kegiatan bisnis yang terorganisir dan dilakukan sekaligus. Kegiatan usaha yang dilakukan dan dilaksanakan secara serasi oleh badan hukum, lembaga sosial dan/atau perorangan yang mengoperasikan air produksi dan sumber air harus mendapat persetujuan dari pemerintah sesuai dengan asas usaha masyarakat dan keluarga.

\section{Pengelolaan Sumber Daya Air yang baik dan benar Berdasarkan Aspek dan Prinsipnya}

Aspek Pengelolaan Pada dasarnya, sumber daya air dikelola hanya dalam satu aspek: bagaimana air digunakan dan ketersediaannya dimanfaatkan. Tapi di mana ada untung, ada kerugian. Ada tiga aspek pengelolaan airtanah yang tidak boleh dilupakan yaitu aspek pemanfaatan, aspek konservasi, dan aspek pengelolaan.

1. Dalam Aspek Pemanfaatan

Salah satu aspek ini selalu ada di benak orang ketika berbicara tentang air. Setelah disparitas antara kebutuhan dan ketersediaan air muncul, masyarakat mulai memperhatikan aspek lain.

2. Dalam Aspek Pelestarian

Agar pemanfaatan selalu lestari, masyarakat perlu menjaga kelestarian air secara kuantitatif dan kualitatif. Juga menjaga daerah tangkapan air di hulu agar selisih perpindahan antara musim kemarau dan musim hujan tidak bertambah. Yang paling penting adalah melindungi air dari polusi.

3. Dalam Aspek Pengendalian 
Air tidak hanya memberikan manfaat namun juga memiliki kerusakan fisik dan kimia yang disebabkan oleh aktivitas manusia. didalam pengelolaan air tanah, sangat penting untuk mengendalikan daya rusak berupa air tanah.

Ketiga aspek penting tersebut adalah satu kesatuan yang tidak dapat dipisahkan satu sama lain. Bila salah satu aspek dilupakan, maka akan mengakibatkan penggunaan udara, bahkan konsekuensi yang sangat buruk. Apabila kita tidak mengelola sumber daya air, akan berdampak sangat buruk baik dalam kehidupan sat ini maupun generasi mendatang.

Prinsip Pengelolaan Air Tanah dimasa mendatang

Ada 5 (lima) prinsip yang mendukung pengelolaan air tanah masa, antara lain :

1. Konservasi

Konservasi yang efektif meliputi suatu langkah pengendalian yang terdiri dari :

a. Perlindungan dan Pelestarian Sumber Air, antara lain :

1. Pemeliharaan kelangsungan fungsi resapan air ;

2. Pengendalian pemanfaatan sumber air;

3. Pengaturan daerah sempadan sumber air;

4. Rehabilitasi hutan dan lahan.

b. Pengawetan Air, antara lain :

1. Menyimpan air yang berlebihan dimusim hujan;

2. Penghematan air;

3. Pengendalian penggunaan air tanah.

c. Pengelolaan Kualitas air upaya aerasi pada sumber air dan prasarana sumberdaya air.

d. Pengendalian Pencemaran pada Air, dengan menghentikan masuknya pencemaran air pada sumber air dan prasarana sumberdaya air.

e. Melakukan kegiatan yang menyuarakan tentang pengelolaan air dengan benar guna mendorong konsumen lebih sadar terhadap akibat penggunaan yang boros.

2. Cara yang paling berkelanjutan untuk menggunakan sumber daya air tanah adalah dengan menggunakannya dengan cara yang memaksimalkan efisiensi. Sumber daya air tanah digunakan dengan mengumpulkan data sumber daya air, menganalisis sumber daya yang ada, mengembangkan rencana jangka panjang, mengeluarkan izin, menerapkan kontrol, dan menegakkan kontrol ini.

3. Mengendalian Daya Rusak Air yang dilakukan dengan cara menyeluruh yang mencakup suatu pencegahan, penanggulangan dan pemulihan air tanah.

4. Sistem Informasi Sumberdaya Air Tanah.

Tujuannya adalah untuk menggunakan sistem yang selalu dapat menangani sumber daya yang dapat berasal dari lingkungan masyarakat, tanpa menggunakan teknologi input eksternal. tidak hanya mencakup pendanaan, tetapi juga sistem dan keterampilan yang dibutuhkan untuk mengelola, memelihara, dan memperbaiki peralatan yang terpasang, dan permintaan partisipasi masyarakat (pilihan teknologi untuk menerapkan dan menentukan pengelolaan), serta perencanaan, konstruksi, dan manajemen). Ini adalah kesalahpahaman umum bahwa sistem saluran pembuangan yang berfungsi 
dengan baik harus memindahkan volume air tertentu per menit. Sistem yang tidak berfungsi atau tidak digunakan oleh masyarakat disediakan sebagai pemborosan investasi sumber daya.

5. Sistem Melingkar (Circular System).

Adalah sistem melingkar. Tekanan keterbatasan jumlah sumber daya seringkali mengharuskan kita untuk mengatur sistem kependudukan, bukan garis lurus. Kota yang membuang polutan ke saluran pernapasan dan menyebabkan masalah bagi orang lain tidak dapat diterima. Air limbah yang diolah, di sisi lain, harus dianggap sebagai sumber air yang dapat digunakan.

\section{Penegakan Hukum Terhadap pelanggaran Izin Pemanfaatan Sumber Daya Air}

Kewajiban menegakkan dan menegakkan hukum merupakan peristiwa yang konkrit (Wiranti, Ikhsan, \& Novianti, 2019). Keamanan hukum merupakan perlindungan hukum yang jelas terhadap kesewenang-wenangan untuk menciptakan situasi tertib yang memenuhi harapan masyarakat.

Tiga unsur yang harus selalu diperhatikan dalam penegakan hukum, yaitu :

1. kepastian hukum (Rechtssicherheit),

2. kemanfaatan (Zweckmassigkeit)

3. keadilan (Gerechtggheit).

Ada 3 cara penegakan hukum lingkungan, yaitu:

1. Melalui Instrumen HukumAdministrasi

Menyelesaikan sengketa administrasi pemerintahan oleh otoritas yang membuat keputusan, atau otoritas atau badan lain yang lebih tinggi dari otoritas yang membuat keputusan. Dengan kata lain, upaya administratif bukanlah keadilan, tetapi penyelesaian sengketa oleh dan di dalam lembaga pemerintah.

2. Melalui Instrumen Hukum Perdata

Ada dua cara untuk menyelesaikan sengketa lingkungan. Yaitu dengan menyelesaikan sengketa melalui mekanisme penyelesaian sengketa di luar pengadilan. Dan penyelesaian sengketa melalui pengadilan.

3. Melalui Instrumen Hukum Pidana

Penegakan hukum lingkungan kepidanaan taklain ialah penegakan terhadap ketentuan-ketentuan pidana dari hukum lingkungan /strafrechtelijk milieurecht. Substansi, kekuasaan kelembagaan dan prosedur umumnya tunduk pada ketentuan hukum lingkungan dan tidak termasuk kecuali diatur lain.

Ada dua jenis pengawasan dalam dokumen hukum administrasi, yaitu pengawasan preventif dan pengawasan represif. Pengawasan preventif adalah mengendalikan dampak lingkungan dan mencegah pencemaran atau kerusakan lingkungan, sedangkan pengawasan represif adalah mengembalikan keadaan semula, menyelamatkan dan mengendalikan kegiatan ilegal tersebut. Pengawasan represif ini dilakukan setelah terjadi pencemaran atau kerusakan lingkungan. 
Hentikan kegiatan ilegal melalui tindakan paksaan pemerintah.

Penegakan hukum yang akan peneliti kaji dalam penelitian ini terkait dengan penegakan hukum lingkungan dan pelanggaran izin.

\section{Kesimpulan}

1. Keadilan harus ditegakan bagi pengguna air, sesuai Pasal 2 UU Sumber Daya Air menekankan prinsip keadilan bagi setiap pengguna air di negara kita, yang mengatur bahwa salah satu prinsip pengelolaan sumber daya air adalah prinsip keadilan. Keadilan yang dimaksud dalam undang-undang berarti bahwa pengelolaan sumber daya air dilakukan atas dasar kesetaraan di semua lapisan sosial masyarakat

2. Tuhan telah memberikan keindahan kepada seluruh umatnya yang sangat luar biasa dalam segala hal di Negara Indonesia, Didalam Pasal 33 ayat (3) Undangundang Dasar Negara Republik Indonesia tahun 1945 (UUD NRI 1945) yang berisi "bumi dan air dan kekayaan alam yang terkandung di dalamnya dikuasai oleh Negara dan dipergunakan untuk sebesar-besar kemakmuran rakyat”.

3. Air adalah kebutuhan hidup. Air dibutuhkan sebagai bahan baku oleh manusia dan sebagai media irigasi, sebagai media produksi bagi banyak aktivitas manusia, dan sebagai media produksi dan tenaga untuk industri dan tenaga listrik. Air sangat penting bagi kehidupan di bumi. Sistem sungai memerlukan air untuk memenuhi kebutuhan hidup manusia, menjaga kestabilan sungai, memelihara dan menyimpan sedimen, serta menjaga kualitas lingkungan. Artinya keberadaan air dalam jumlah, kualitas dan waktu tertentu diharapkan dapat menjamin keberlangsungan kehidupan manusia dan lingkungan.Air merupakan kebutuhan hidup manusia dan tidak dapat digantikan oleh barang lain, sehingga air harus diperlakukan sebagai barang publik. Komodifikasi sumber daya air yang telah memisahkan sumber daya air menjadi beberapa jenis yang dapat memutus siklus hidrologis alami sumber daya air, semakin mempersulit pengelolaan sumber daya air secara terpadu. 
Kartika Chandra Kirana.

\section{Bibliografi}

Barthes, Roland. (2012). Elemen-elemen semiologi. Basabasi.

Jocom, Hary, Kameo, Daniel D., Utami, Intiyas, \& Kristijanto, A. Ign. (2016). Air dan Konflik: Studi Kasus Kabupaten Timor Tengah Selatan. Jurnal Ilmu Lingkungan, 14(1), 51-61.

Maridi, Maridi. (2015). Mengangkat budaya dan kearifan lokal dalam sistem konservasi Tanah dan Air. Proceeding Biology Education Conference: Biology, Science, Enviromental, and Learning, 12(1), 20-39.

Pasal 1 Ayat (3) Undang-Undang Nomor 11 Tahun 1974. (1974). Tentang Pengairan.

Silalahi, M. Daud. (2008). Pengaturan Hukum Sumber Daya Air dan Lingkungan Hidup di Indonesia. Bandung: Alumni.

Soraya, Noni. (2014). Infused Water: Minuman Alami Bervitamin \& Super Sehat. Penebar PLUS+.

Sudarwanto, A. L. Sentot. (2015). Dampak Dibatalkannya Undang-Undang Nomor 7 Tahun 2004 Tentang Sumber Daya Air Terhadap Manajemen Air Untuk Kesejahteraan Masyarakat. Yustisia Jurnal Hukum, 4(2), 456-474.

Suntari, Lilik. (2017)._Dinamika Pengelolaan Sumber Daya Air di Desa Pudak Kulon Kecamatan Pudak Kabupaten Ponorogo. UNIVERSITAS MUHAMMADIYAH PONOROGO.

Tesha, Brigita. (2019). Evaluasi Kelembagaan Sumber Daya Air: Studi Kasus Pengelolaan Sumber Air Minum Di Desa Samaenre Kecamatan Mallawa Kabupaten Maros. Universitas Hasanuddin.

WIRANTI, HERDALENA, Ikhsan, Rd, \& Novianti, Vera. (2019). Upaya Kepolisian Dalam Menegakkan Hukum Terhadap Pelaku Tindak Pidana Tabrak Lari Di Palembang. Sriwijaya University.

Putusan Mahkamah Konstitusi Nomor 85/PUU-XI/2013 Tentang Pengujian

UndangUndang Nomor 7 Tahun 2004 Tentang Sumber Daya Air.

Pasal 33, Peraturan Pemerintah Nomor 121 Tahun 2015 Tentang Pengusahaan sumber Daya Air.

Pasal 52, Peraturan Menteri Pekerjaan Umum dan Perumahan Rakyat Nomor 01/PRT/M/2016 Tentang Tata Cara Perizinan Pengusahaan Sumber Daya Air dan Penggunaan Sumber Daya Air. 